Ademir Valdir dos Santos

Universidade Federal de Santa Catarina, UFSC

E-mail: ademir.santos@ufsc.br

(D) https://orcid.org/0000-0002-5958-689X

\section{Education and faith: Luther ideas, German immigration to Brazil and the community- organized schools (19th-20th centuries)}

\section{Ademir Valdir dos Santos}

\section{Abstract}

The research aims to analyze, based on the relations between German immigration, Lutheranism and the process of creation of schools, the historical incorporation of ideas on education of Luther and its influence in the south of Brazil, in a period between the second decade of century XIX and the first decades of the twentieth century. The methodology is characterized by documentary research with the use of sources referring to the creation of schools, discussed based on a bibliographic reference that includes Luther texts and studies that deal with the links between religion and schooling. The results highlight the importance attributed to the school by Luther, understanding him as a religious reformer of Education. They show that the creation of schools by groups of German Lutheran immigrants in the Brazilian South is justified by their foundation in Lutheran conceptions. The schools were created so that children and young people could have access to religious principles and overcome the difficulties of living in a cultural environment different from that of the regions of origin. These reasons were reinforced by the absence of primary schools maintained by the government, either in the Empire period or in the first decades of the Republic. It is concluded that community schools founded on the colonies meant responses to the divine call to act in human education in harmony with faith, being understood as a result of Lutheran inspiration.

Keywords Martin Luther; Immigration; Education; Faith.
Recebido em: 15/03/2019

Aprovado em: 17/07/2019 
Resumo

Palavras-chave:

Martinho Lutero; Imigração;

Educação; Fé.
Educação e fé: as ideias de Lutero, imigração alemã para o Brasil e as escolas comunitárias (séculos XIX-XX)

A pesquisa objetiva analisar, com base nas relações entre imigração alemã, luteranismo e o processo de criação de escolas, a incorporação histórica de ideias sobre educação de Lutero e sua influência no sul do Brasil, num período entre a segunda década do século XIX e as primeiras décadas do século XX. A metodologia é caracterizada por pesquisa documental com a utilização de fontes referentes à criação de escolas, discutida com base em referencial bibliográfico que inclui textos de Lutero e estudos que tratam de vínculos entre religião e escolarização. Os resultados destacam a importância atribuída à escola por Lutero, compreendendo-o como um reformador religioso da Educação. Mostram que a criação de escolas por grupos de imigrantes alemães luteranos no Sul brasileiro é justificada pelo seu fundamento em concepções luteranas. As escolas foram criadas para que crianças e jovens tivessem acesso aos princípios religiosos e superassem as dificuldades para viver num meio cultural diferente daquele das regiões de origem. Estes motivos foram reforçados pela ausência de escolas primárias mantidas pelo governo, seja no período do Império como nas primeiras décadas da República. Conclui-se que as escolas comunitárias fundadas nas colônias significaram respostas ao apelo divino de agir na educação humana em consonância com a fé, sendo compreendidas como resultado da inspiração luterana..

\section{Resumen}

Palabras clave: Martin Lutero; Inmigración; Educación; Fe.
Educación y fe: las ideas de Lutero, inmigración alemán para Brazil y las escuelas comunitarias (siglos XIX-XX)

La investigación objetiva analizar, con base en las relaciones entre inmigración alemana, luteranismo y el proceso de creación de escuelas, la incorporación histórica de ideas sobre educación de Lutero y su influencia en el sur de Brasil, en un período entre la segunda década del siglo XIX y las las primeras décadas del siglo XX. La metodología se caracteriza por la investigación documental con la utilización de fuentes referentes a la creación de escuelas, discutida con base en referencial bibliográfico que incluye textos de Lutero y estudios que tratan de vínculos entre religión y escolarización. Los resultados destacan la importancia atribuida a la escuela por Lutero, comprendiéndolo como un reformador religioso de la Educación. Muestran que la creación de escuelas por grupos de inmigrantes alemanes luteranos en el sur brasileño está justificada por su fundamento en concepciones luteranas. Las escuelas fueron creadas para que niños y jóvenes tuvieran acceso a los principios religiosos y superaran las dificultades para vivir en un medio cultural diferente de aquel de las regiones de origen. Estos motivos fueron reforzados por la ausencia de escuelas primarias mantenidas por el gobierno, sea en el período del Imperio como en las primeras décadas de la República. Se concluye que las escuelas comunitarias fundadas en las colonias significaron respuestas al llamamiento divino de actuar en la educación humana en consonancia con la fe, siendo comprendidas como resultado de la inspiración luterana. 


\title{
Introdução
}

The history of the arrival of Lutheran Protestantism in Brazil is strictly related to the history of German immigration that has occurred more intensely during the 19th and 20th centuries. Some of the factors of expulsion of the Teutonic population that used to afflict the Germanic territory at that time: climatic problems that have caused floods and bad crops, the familiar organization model that destined the father's heritage to only one of the sons who was authorized to get married (the eldest or the youngest, for example) and excluded the other sons from these rights by demanding that they work for the heir, the forms of work organization from feudalism or that still kept the "white slaves" (Leibeigene), disputes and discontentment with a religious background, generated by the struggle between the Lutheran and Reformed Churches under the imposition of Prussia (1817) and political issues by the time of the Socialist Revolution of 1848. Due to these aspects, millions of Germans saw in immigration a possibility of escaping the difficult conditions of local reality and intended to find a better situation for their family in another country. The movement of people was bigger towards the United States, but it has also had South America as destination.

The affirmation is common that the community organization centered in Lutheranism in Brazilian lands only occurred in the period of the Empire. But this does not prevent one from recalling the presence, in the course of the history of Brazil, of people who professed the evangelical faith. According to the Evangelical Church of Lutheran Confession in Brazil (IECLB):

\begin{abstract}
In the course of the Brazilian history there has always been the presence of people who were linked to the evangelical faith. Among the first evangelical Lutherans, one highlights: Heliodor Hesse - a registrar who resided in São Vicente-SP, a son of the German humanist Helius Eobano Hesse, a friend of Martin Luther who arrived in Brazil around 1554, and Hans Staden, who sang hymns of Luther and erected the first evangelical chapel while he was a prisoner of the Indians in Ubatuba/SP in 1554. Remember also that in Rio de Janeiro was celebrated the first evangelical cult in Brazil and were executed the first three Brazilian (Calvinist) evangelical martyrs in 1558. In Sorocaba, State of São Paulo, the first Protestant cemetery was created by the time of the implantation of the first Brazilian steel company by the royal family in 1811.

(http://www.luteranos.com.br/portal/site/conteudo.php?idConteudo=1158).
\end{abstract}

A policy of attraction of German immigrants was created at the time of the Empire, under the governments of Dom Pedro I and Dom Pedro II. This action was stimulated by reasons of economic nature once there was the intention of replacing the slave labor that was predominant up to 1888 . In this sense, the possibility that the immigrants could come to have portions of land within the Brazilian territory was certainly one of the factors that motivated 
the coming of foreigners. But it was also fed by the idea that the Germans would be good settlers, good citizens and even good soldiers to guarantee the huge borders.

The essential aspect to make evident is that among the immigrants there was a group of individuals whose religion was Protestant. Particularly, a great number of Lutherans. But their arrival caused problems exactly because the Brazil of that time was a Catholic country. In the Constitution of Brazil under the Empire, of 1824, there appears in article 179, paragraph 5: "No one must be persecuted because of their religion, provided that they respect the religion of the State and do not hurt the public moral”. However, in spite of what was announced about a religious freedom, article 5 maintained that: "The Roman apostolic Catholic religion will continue to be the religion of the Empire. All the other religions will be permitted with their domestic or particular cult, in houses destined to this, without an external form of a temple”. One has created, thus, a series of hurdles for the effective practice of a Protestant religion. One suggested a confinement in private environments and that one should not offer visibility to the places of cult. And even the Criminal Code of the Empire brought in its article 276: "Should members of a religion, which may not be the one of the Empire, celebrate their cults in a building that may have the form a temple, they must be dispersed by the peace judge and be punished with a fine of 2 to 12 mil-réis”. Even political rights were limited to the non-Catholics, according to article 95 of the Constitution: "People who profess a religion other than the one of the Empire cannot be deputies".

In spite of the difficulties then existing, the first Lutheran evangelical communities were being founded. According to Weingaertner (1997), on May 3rd, 1824 there came to Rio de Janeiro and settled in the region of Nova Friburgo the first 300 German immigrants, being most of them Lutherans. Most came from the County of Hesse and was accompanied by the Pastor Friedrich Sauerbronn. The first Lutheran pastor in Brazil, Sauerbronn used to receive his salary from the Imperial government. Also the German colonization of the South of Brazil started on that year, with the arrival to the State of Rio Grande do Sul of a group that settled in the town of São Leopoldo and that counted from the start on the action of Pastor Johan Ehlers. In the neighboring States of the South, Santa Catarina and Paraná, the first German immigrants arrived in 1828 and 1829 and founded São Pedro de Alcântara and Rio Negro, respectively. But, although there were Protestant families, these have not formed Evangelical Communities. Later on, between 1846 and 1847, other colonization initiatives occurred in the States of Minas Gerais, Espírito Santo and again in Santa Catarina. Although these groupings were of a Lutheran majority, they had not had a pastoral service for 15 years. Pastors from Basel (Switzerland) arrived to these places in 1861. 
Particularly in the region of the Southern State of Santa Catarina, isolated communities were being constituted. In Blumenau, for example, it was seven years after its foundation, which took place in 1850 that Pastor Rudolph Hesse arrived. In Joinville, another outstanding region in the colonization process with German immigrants that was founded in 1851, Pastor Jacob Hoffmann arrived on the same year. The town of Brusque received Pastor Johan Sandreczki in 1865; at Estrada da Ilha Pastor Heinrich Feinauer arrived in 1864; in 1888, Pastor Wilhelm Quast arrived in São Bento do Sul and Pastor Wilhelm Lange came to the region then called Bruderthal in 1886. In 1866, in the State of Paraná, the city which is today its capital, Curitiba, watched the formation of its 1st Evangelical Community, the leadership of which was left to Pastor Friedrich Gaertner, who has as his previous occupation the one of teacher. Observe that the communities scattered across the territory of the South of Brazil were independent and little linked to each other.

The pastors who took on the leadership in the communities have faced hard work. It happens that the immigrants came from different regions of Germany and had different Protestant traditions, being some Lutherans, others reformed (a branch that was originally Lutheran but that formed itself with a schism in 1555) and others united (as called by themselves the members of the United Church of Prussia, which was the work of King Friedrich Wilhelm III, in 1817). But observe that there was a first basis that oriented itself by the thought and action of Martin Luther.

In fact, it was only from 1881 that an association called Evangelische Gesellschaft fuer die protestantischem Deutschen in Amerika started to mediate the coming of pastors from Europe to the communities located in the provinces of Brazil. There was also the action of the so-called Gotteskasten, which devoted itself to sending Lutheran pastors to various regions. Thus Pastor Otto Kuhr, sent by the Gotteskasten, arrived at the port of São Francisco do Sul in 1897 and immediately started the works at the community of Estrada da Ilha. The pastors sent by this organization had all been trained at the seminar of Neuendettelsau and were partisans of the Lutheran Liturgy of the Bavaria. It is said that 10 pastors have led communities scattered across Santa Catarina, Paraná, and Espírito Santo between the end of the 19th century and beginning of last century (WEINGAERTNER, 1997).

This way, the form of organization of some of the communities constituted in Brazil had as one of their foundations the presence of a pastor. The presence of pastors with different trainings and origins has generated conflicts. Observe that in 1896 was held the 1st Pastoral Conference of Santa Catarina, congregating the local pastors arrived until then. Such conferences used to happen twice a year and dealt with the ecclesiastical work and theological 
studies. But they have also generated important facts for fixing and spreading the Lutheran ideas, for at that first meeting the presents have decided to take on two newspapers that were already being edited: Der Urwaldsbote (which was edited since 1893) and Sonntagsblatt fuer di Evangelischen Gemeinden in Santa Catarina (this one dated from 1895). The press has configured a fundamental link between the evangelical communities. On their turn, the pastors of Gotteskasten, who have arrived later, have also founded a Lutheran Pastoral Conference, in 1899, and therefore have not associated themselves to the other active pastors. Moreover, in 1905 they launched their own ecclesiastical newspaper: Evangelisch Lutherisches Gemeindeblatt. And on the same year they ended up founding their own synod, the Lutheran Evangelical Synod of Santa Catarina, Paraná and other States.

Following another orientation, even though in the common sphere of propagation of the Lutheran faith, the other pastors founded in 1911 the Evangelical Synod of Santa Catarina and Paraná, also called Association of the Communities.

The divergences of confessional origin and which in a certain way have been imported from Europe have persisted until 1949, when the Synods then existing in Brazil united themselves and founded the Synodal Federation which, on the following year, adopted the name of Evangelical Church of Lutheran Confession in Brazil.

Although this history of institutionalization of religion of Lutheran basis is one of the Fundamentals of fixation of the ideas of Martin Luther in the Brazilian lands, it is important to remember that in many regions it was the followers themselves who needed to organize their religious life, since there were no pastors.

Fischer (1984, p.59-60) ratifies that Protestantism has existed in Brazil, in a permanent way, since the beginning of the 19th century. He also supports the argument that initially almost all the evangelicals in Brazil were immigrants and descendants of immigrants, mostly of German origin. For this, with their arrival there has also started the presence of Luther's ideas in the country, once they brought from Germany the heritage of faith. This does not mean that the presence of non-Catholics was something peaceful. For Schneider (1983, p.188), once until the end of the Empire Brazil was absolutely Catholic: “A Protestant, here in Brazil, was a HERETIC. The same as a Jew [...] In the invitation made in 1820 by Dom João VI were EXPRESSLY EXCLUDED THE EMIGRANTS WHO WERE NOT CATHOLIC”.

Even facing a hostile environment, the Protestant-based faith and the fundamentals proposed by Martin Luther that have installed themselves here have given support to the religious permanence and based its institutionalization. 
Fischer (1984, p.60) remembers two documents considered fundamental for the maintenance of Luther's thought in Brazil:

First, Luther was present by means of the Bible, which the immigrants brought in the German language, in Luther's translation. The "Luther's Bible" (Lutherbibel) has always been a kind of national treasure of the evangelicals who speak German. It had occupied, for this reason, an outstanding place in their life of faith. Luther, the translator of the Bible, was the one who has made possible the people's direct access to the biblical message, without the Church-institution as an intermediary.

Second, Luther was present by means of his hymns. For a long time they were sung in the German language. Initially hymnals from Germany were used. Later on, hymnals in the German language were printed here. The hymnal of IECLB in the German language, in the edition of 1958, contains among its 387 hymns 20 which are of Luther.

In the work of Klug, a Lutheranism scholar in Santa Catarina, the preface signed by Martin Dreher, another researcher of the issue, reaffirms:

In their baggage, the immigrants used to bring little. The little, however, many times characterizes the group. In this sense the religious baggage deserves to be highlighted. In the immigrants' trunks we find, most of the times, two, sometimes three, books. The Hymnal, the book of religious chants, the Minor Catechism of Luther and the Bible. [...] From these books, religiosity continued to be nourished and kept. As the religious life causes communitariness and makes survival possible, almost naturally, the immigrants have re-organized their religious life in Brazil. (KLUG, 1994, p.14).

The fact of being a Lutheran Protestant in traditionally Catholic lands has generated an identity element typical of the German immigrants. Among the documents found in the research, an "Ecclesiastical Identity Card” was located, having been issued by the Evangelical Community of Corupá, in the State of Santa Catarina (a settlement that was originally called Hansa Humboldt), which attested to the belonging to the Lutheran community of the family of August Neitzke (Figure 1). From the notes on the document, it was utilized in the 1940's (COMUNIDADE EVANGÉLICA DE CORUPÁ, [194?]).

Figure 1 - Ecclesiastical Identity Card - [194?] - Source: Private archive.

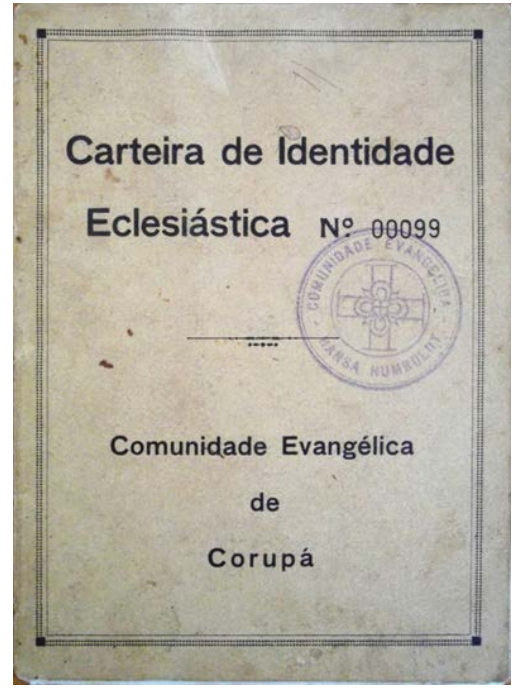


Thus, the religious belonging, as an element of constitution of an ethnical identity, constituted the communitarian social organization linked to immigration and served to distinguish Luther's followers. Such an argument combine with other studies, as the one of Gobbo (2001), which, on analyzing the issue of cultural continuity, education and religious identity of Waldesians who had migrated to Italy, shows how minority groups tend to differentiate themselves as to this condition exactly for constituting religious and migratory minorities. Among other questionings, Francesca Gobbo has oriented herself by the following:

The question I asked myself was to which extent the process of schooling, and the ideal of education, still played a meaningful role in the process of acquiring an identity as a Waldensian - given that over the year so many things have changed in the political, social, cultural and educational context of the valleys, and of the whole Italian nation. (GOBBO, 2001, p.31).

From an old Lutheran hymnal, a document which can also be understood as building a specific identity, we have extracted verses that show the invocation of the divine look at the new reality with which the immigrants have found themselves, a new homeland where their ideals can - or not - be made come true. For this reason, it was necessary to persevere:

Oh God omnipotent,

Let your so merciful hand

Govern our home!

The shaken homeland, the Church united in Thee

Benign, may You protect! (HYMNS OF THE EVANGELICAL CHURCH OF LUTHERAN CONFESSION IN BRAZIL, [s.d.])

The religious phenomenon is at the same time individual and social, personal and communitarian. In its breast there is always an unceasing inter-relation and interaction of the individual with the social group and vice versa, between a member of the community and the community as a whole. That is, one strongly connects the social framework to the religious framework and hence we can derive a potential in the characterization of objectives and in the organization of actions that can, thus, be generated and kept inside a given group under the religious influence:

...the complexity of the social structure of a religion intimately depends on the very complexity of the social structures of which it forms part. A society in progress tends to differentiate and organize itself: a judicious distribution of functions has more efficiency in the execution of more and more complex tasks. To this 
diversification of functions corresponds a diversification of powers - hence the appearance of several degrees of participation in the life of the group, each with its respective rights and duties. (LAGENEST, 1976, p.37).

In the deep analysis that Fernández-Armesto \& Wilson (1997, p.397) make of the phenomenon of the Reform and of its impacts for 500 years of history of mankind, there is also this agreement with the fact that "the evangelical values and beliefs permeated society, but in an imperfect way, and this is the reason why one compiles varied impressions in the contemporary reports and in the historical analyses. On the basis of the previous arguments and with which we agree, we start to deal with one of the communitarian initiatives of the Lutherans, typical of their movement of survival and insertion in the Brazilian society: the creation of schools of their own.

The importance attributed by Luther to school is revealed on the basis of two classical texts which permit to position him as a religious reformer of Education: To the Councilmen of All the Cities in Germany that they Establish and Maintain Christian Schools (1524) and On Keeping Children in School (1530). In the analysis of Beck (1995, p.301):

These writings do not end up formulating a Christian theory of education. They serve, however, to justify the effort for the good education that has characterized the Lutheran communities and the leaders since the Reform. As Luther, we feel responsible for the future generations. That is why we fight in and for education.

This is what one has watched in the settlements of German immigrants, where there was a high percentage of Lutherans during the 19th and 20th centuries and who have settled mainly in the lands of the South of Brazil. The principles that defended the education of children and youngsters as essential have certainly motivated the movement of creation of community-organized schools as an initiative of the adult generations that wanted schools for their children to have access to the fundamentals of faith and also to be trained to face the difficulties of life in a foreign country and with very different cultural habits.

In a deposition collected in 1998 from a descendant of a Lutheran immigrant of the first generation, Willy Julio Otto Früchting, who was then 86 years old, one observes the meaning of the school that remained and motivated the community's effort in erecting a school:

\footnotetext{
...it was very expensive to make that school. My father used to tell that there they found the bricklayer who was a settler. [...] They asked him to make the school, and he made it, very cheap, he used to charge little per day. And then the settlers helped: one helped today, the other, tomorrow. They were going to unite themselves not to spend anything! They wanted to send the children to school. My father helped, all helped. [...] There was a school society there. [...] It built this to give some school to the children. [...] The children are born, grow up and have no school!
} 
Through his words, which have found echo in the speech above, Luther himself had alerted for the fact that not sending the children to school contributes to the destruction of the holy Gospel and of the kingdom of God, or at the very least it generates hurdles for the divine will to be made come true among us; in short, it corresponds to one of Satan's strategies in his attack against mankind: “Among his tricks, one of the most important (if not the most important) consists of stunning and cheating simple people in such a way as they do not want to send their children to school nor forward them to study" (LUTERO, 1995, p.331).

This issue was reinforced by the almost total absence of primary instruction schools for the Brazilian population at that historic moment (WEREBE, 1995; NAGLE, 1997). More precisely, for Werebe, who makes an analysis of the educational heritage that has remained from Brazil-Colony (1500-1822) and from the Empire (1822-1889) for the beginnings of the Republic, this form of political organization started at the end of the 19th century and kept until the present, the following is the built scenario:

\begin{abstract}
Summarizing, we can say that the Republic has come to find the country, in the education field, with a very needy primary school network, with a predominantly lay and incapable teaching personnel; a secondary school attended exclusively by the children of the economically favored classes, maintained mainly by privates, administering a literary teaching, completely unlinked from the needs of the nation; an upper teaching misrepresented in its objectives, and still - maybe this is the worst of the heritages received - with the misrepresentation of the spirit of education in all the degrees of teaching. The Republic has not had to face a simple quantitative deficiency, but - what was more serious and more difficult of being modified - a qualitative deficiency. (WEREBE, 1995, p.382-383).
\end{abstract}

That is, the absence of actions to offer schools for the people summed up in the plan of ideas to Luther's exhortation for the State to open and maintain schools. This way one used to configure on two bases the reality of the absence of school training. This has vigorously driven the immigrants and their descendants to fight for the opening and maintenance of their own schools, since one could not admit of lacking school to children and, at the same time, rare were the existing institutions, be it in the imperial period, be it in the republican one, corresponding to the arrival of the Lutheran Germans in Brazil. Therefore, the Brazilian - and Catholic! - Government did not satisfy that rather vehement request by Luther for schools to be opened and maintained. In the exhortation made in the 16th century to the mayors and town councils of Germany so that they took the trouble to create and keep Christian schools, a solid fundamental for the spread of the Christian humanistic education across Europe and which echoed in the minds of the Lutherans, one reads:

For this reason it will certainly be of the competence of the council and of the authorities to devote the greatest care and the maximum commitment to youth. To them, as curators, one has trusted the belongings, honor, body and life of all the 
town. Therefore, they would not act responsibly before God and the world if they did not search, by all means, day and night, the progress and the improvement of the town. Now, the progress of a town does not depend only on great treasures, on the construction of fortified walls, on beautiful houses, on many canons and on the manufacturing of many armors. [...] Long before, the best and richest progress of a town is when it has many learned men, many wise, honest, and educated citizens. Then, these can also correctly accumulate, preserve, and use riches and all kinds of assets. (LUTERO, 1995, p.309).

Luther's word used to nourish the ideal of progress of the communities, based on the offer of good education for children and youngsters. Thus, as a heritage brought by the immigrants, it has driven them in the tough tasks of carrying out in the settlements installed in Brazilian lands a work that would destine the community to progress. And, for this, having schools was fundamental.

Here we can speak of a Lutheran ethics that has taken on a collective dimension of work and construction. According to Dreher (1984, p.29):

\begin{abstract}
From there we can understand that Luther's ethics is not valid for all the times, but it is a survival ethics in tough times. It is ethics in the context of chaos and danger, it is not law, but adaptation to the need of the time. [...] Until the last hour, human being has the task of taking care of God's world. In this - and only in this - he is a cooperator of God. To those who escape this commitment, God will punish, even if they have had many masses prayed, participated in pilgrimages and fought against heretics. Running after salvation and abandoning the family, house, and home is not a good work. Then who gets joyful is the devil, for we help him promote chaos. The devil makes a party when the Christian stops.
\end{abstract}

The creation of a system of schools at the communities of Lutheran German immigrants who have settled in the South of Brazil can be justified by its being based on Luther's conceptions. The foundation work of a school is a fruit of faith. For this reason, we maintain that the Lutheran immigrants and their family members tackled the secular tasks while spiritually fed by the Lutheran ideas, by the strong belief. The schools erected amidst the settlements represented the reply to the divine request of intervening in the human education in the light of belief.

The same way, in an article entitled Luther and Education, we find the defense of materialization, through the foundation of schools by the immigrants, of the connection between the Lutheran ideal and the teaching that would have deeply influenced the thought of the Protestant Germans. The school is essential to man's life.

In the beginnings of the IECLB the creation of communities and schools used to happen jointly; the pastor was often simultaneously a teacher and vice versa; even today the church and the school are side by side in many places. Moreover, one cannot fail to consider that Luther, in his preaching and writings, broaches over and over issues related to education, besides writing some texts in which he concretely focuses on education problems and which have been called 'pedagogical writings'. (VOLKMANN, 1984, p. 94). 
In a detailed historic analysis about the immigrants' schools installed in the Brazilian South, more particularly in the State of Rio Grande do Sul, institutions that have also been called Teutonic-Brazilian schools, Müller (1994, p.67) makes evident the link between the phenomenon of creation of schools and the influence of Luther, as well as the positive impacts of this initiative for the population's literacy:

\begin{abstract}
These immigrants have produced a cultural world of their own since 1824. The immigrants were literate, most of them being of Evangelical confession. Luther, in Germany, on preaching the "believers' general priesthood", had become a sewer of schools because, in his rupture with the Catholic Church, it has become clear to him that each believer should know how to read to better understand the Bible, an indispensable daily reading. This search for literacy has been transposed to the south of Brazil where the legacy of literacy for the transmission of knowledge and the search for cultural survival have ended up creating the so-called "German Settlement of São Leopoldo" and settlements in other regions of the State, as History registers it.
\end{abstract}

In general, the community could start its schools by occupying the spaces built for another purpose, as the settlers' residences. There are also many reports of the option for erecting a building that would serve at the same time for the religious cult and teaching and for housing the schools, which has given rise to the "school-chapels". In general, after the groups of immigrants had already managed to erect an infrastructure with more elaborate buildings for the residence, it is when they strove for the construction of a specific building for their school. According to Müller (1994, p.69), in 1937 there were 513 Evangelical schools served by around 650 teachers in Rio Grande do Sul.

About the creation of schools in immigrants' settlements in the territory of the State of Santa Catarina, Santos (2008, p.3-4) describes the movement of their implantation in an area which had been populated by groups of Germans of Lutheran majority who occupied lands commercialized by the Hanseatic Colonizing Company of Hamburg (Hanseatischen Kolonisations-Gessellschaft):

We have verified in the various reports sent by the local Board of Directors of Hansa
Settlement that in 1904, that is, within a period of six years following its foundation,
there were already four schools in Humboldt: in the "town” (Stadtplatz), on Isabel
road (Isabella-Strasse), on Paulo road (Paul-Strasse) and on Bonpland and
Humboldt road (Bonpland und Humboldt Strasse). In another district, Itajaí-
Hercílio, five schools were already functioning: Hammonia, Sellin, Rafael, Neu-
Bremen and Neu-Zürich. There was one in São Bento and another in Piraí (Bericht
der Kolonie-Direktion Hammonia..., 1905, p. 13). As for their origin, some of the
schools have been founded by private associations or school societies (Schulverein
ou Schulgemeinde), which had as members the local families, others were linked to
the Evangelical church.

Documents located show that the colonizing societies with their seat in Germany, as the Hanseatic Colonizing Society, have invested in the construction of schools: a definitive 
form of title grants to the Sociedade Escolar Rio Novo, located in the Northeast of the State of Santa Catarina, a colonial lot for school construction (TÍTULO DEFINITIVO DE PROPRIEDADE, 1918); an obligation document dated of 1929, signed by the Board of Directors of that same Colonizing Society, registers the loan of two hundred and fifty mil-réis, without interest and for an undetermined term, made to the Sociedade Escolar Paulstrasse so that this one should build the building to house the classes (OBRIGAÇÃO, 1929). And both schools quoted were linked to the Lutheran Evangelical Church of the then Hansa Humboldt settlement.

As for the teachers' staff that acted at schools, there are registrations that in some cases teaching was an activity to which the pastor devoted himself. But as the geographical area under occupation was big, in various localities the teacher was indicated by the settlers themselves, with the choice falling on someone with a more solid schooling and who could work with the children. In the rural communities that housed Teutonic-Brazilian schools the figure of the teacher used to take on a varied importance. The prerequisites required from someone for the teaching function were not always noble. Willems (1980, p.280-1) reports that "the first teachers who offered themselves were invalid people who could not work in the plantations"; [therefore] "the choice of the teacher used to obey, from the start, a negative principle: only useless individuals for other activities became masters”. According to the author quoted, the teacher's salary was prorated between the settlers interested in the schooling of their children. As for some localities, the teacher came from the outside, installing himself in the community, where by necessity he complied not only with the teaching, but also grew the land and raised animals, which helped subsist in the rural environment. The teaching prestige was variable, being that in some communities, the teacher has acquired, gradually, a positive status, linked to some economic stability.

In some more thriving localities it was possible to count on a teacher from Germany. And in the first decades of the last century the schools started to have teachers trained in Brazilian institutions as the school groups and institutes specializing in teachers' training which have been created linked to the religious associations. The creation process of a Teachers' Association (in 1898), as well as the one of a Normal School (in 1923) destined to the teachers' training in Rio Grande do Sul is detailed, for example, in the work of Rambo (1996). For this researcher, the first seventy years of experience of foundation of schools by immigrants have been marked by the implementation of more modest institutions and the teachers who performed did not have, in general, a professional authorization, acting in a dedicated manner to the school work. But the historic need of discussing a curriculum unity 
and of employing teachers with a more solid training has generated the conditions for the foundation of institutions for the preparation of the teachers who performed as the communitarian schools of the colonial areas.

In general, in the initial years of functioning of the school, the teaching was made in the German language and the curriculum focused on this foreign language and disciplines that focused on the European culture. The didactic materials included books and manuals imported or produced in local publishing houses which printed them in the foreign language. Reports located in the State Archive of Hamburg (Staatsarchiv Hamburg), in Germany, which contain descriptions of the teachers' activity in settlements of Santa Catarina between the years of 1899 and 1911, show that in primary communitarian schools active in this area of the Brazilian South one used to teach Religion, Calculus, Reading, Dictation, Writing, Composition, World History, Portuguese, Natural History, Singing, Handicrafts and Geography (Auszug..., 1905). But this does not mean that one did not carry out studies about aspects of the Brazilian culture and privileging the Portuguese language. In the report by the Board of Directors of Hamônia, of 1904, it appears that in the last year, the Teaching of the Language was associated to the discipline of Portuguese (Portugiesisch), which makes evident the concern about its daily utilization in the children's training, for the children were amidst the Brazilian society. Natural History (Naturgeschichte) was a curricular component only of the third and fourth years, in which one used to study animal realms (animal, vegetable, and mineral). Curiously, the foreign contents mixed with the typically Brazilian ones. The teacher said that one used to list the exclusive species of the fauna and flora of Brazil, as the fowls (Kolibri, referring to the hummingbird, or Jakutinga, for jacu) and other animals (Mico, for this species of small monkeys). One still used to study domestic animals as horses and dogs. Vegetable species important in the rural life, as the corn, also appeared in the lessons. Another particular discipline quoted is National History (Heimatkunde), in the third year, broaching the very locality where the school was situated, the Valley of the Itajaí (Das Tal des Itajahy). Thus, in the fourth section there was the discipline of History, broaching the Discovery of Brazil and the constitution of the settlement itself. The same happened with Geography (Erdkunde), which broached aspects of the Valley of the Itajaí, of the States of Santa Catarina, Paraná, and Rio Grande, side by side with more comprising contents as the various parts of the world, the oceans, the South and North Americas and Europe (JAHRESBERICHT $1904 \ldots)$. For this reason one can say that in the course of time there has been a continuous increase in the ratio of contents linked to the Brazilian reality in the curriculum of those foreign schools installed. This shows that, in various cases, the German schools focused on 
aspects of the Brazilian reality, that is, such issues were not de-valued, as spread by the nationalistic ideas of the 20th century.

But it was exactly this ambiguity of treatment of the cultural issues that has ended up building a vision that the so-called German schools meant an obstacle to the construction of the Brazilian nation according to the nationalistic ideas that have come up and become steady in the first decades of the last century. In fact, the pedagogical practices have contributed to the perpetuation of an ethnical identity that contrasted with the Brazilian environment. For this distinction between the groups of immigrants and the local population various factors have contributed, as the existence of other social institutions and cultural activities - besides the school - created and maintained by the foreigners. One can quote the associations of singing, dance, gymnastics, shooting practice, balloon, and the circulation of newspapers, magazines, almanacs and calendars in the German language and the Protestant churches. All this has functioned as a social cement that has produced solidarity and social cohesion based on the maintenance of cultural attitudes and traditions of Germanic origin.

For these reasons the German immigrants and their descendants have been persecuted and seen as a threat during the nationalization campaign of the dictatorial government of Getúlio Vargas (1937-1945), a period called “Estado Novo” (New State). Nationalism was more intense at that time, but policies of this nature had started already in the period contemporary to the I World War and continued in the following decades.

In 1938 the German schools were prohibited by federal decrees: Decree-Law n 383 , of April 18th, 1938, which prohibited to foreigners the exercise of political activities in Brazil; Decree $\mathrm{n}^{\circ} 406$, of May 4th of the same year, which regulated the entry and permanence of foreigners, determining measures for their assimilation, and formed the Immigration and Colonization Council as an executive body of its provisions; Decree $\mathrm{n}^{\circ} 868$, of November 18th, 1938, which created the National Commission of Primary Teaching, with attributions as for the nationalization of teaching in the foreign centers and still Decree $\mathrm{n}^{\circ}$ 948, of December 13th of the same year, which, considering complex the measures to promote the assimilation and the complete nationalization of the foreigners' children, established they should be made effective by the Immigration and Colonization Council (BOUMENY, 1999, p.158). Thus, one has tried to ban the usage of the German language and the functioning of all kinds of cultural institution of Germanic origin. The principals and teachers of the schools had to be Brazilian born and must master the Portuguese language. As for this wave of closing of schools, Müller (1994, p.71) informs that in 1941 their number fell from 513 to 120 . 
The nationalization campaign during the New State took on such a character which for many scholar can be considered a fascist initiative. In his study about that regime and the Lutheran Evangelical Church, Dreher (1994, p.87) maintains that it is regrettable to inform that the researches “...have evidenced that the group mostly hit by the repressive measures of the Brazilian fascism, led by Getúlio Vargas, on the sphere of Rio Grande do Sul, has been the Evangelical-Lutherans”.

However, the Fundamentals of "Germanity” and Lutheranism had already created deep roots. Kreutz (1994, p.56-7), for example, maintains that, although the government had sought to close the Teutonic-Brazilian parochial schools, what has more often occurred was a search for their adaptation to a rather exacerbated nationalism; it results that attributing the end of the Teutonic-Brazilian school to the Nationalization Campaign is a wrong affirmation, for it would be correct to speak that what has occurred was the acceleration of the historic transformations that that school institution would end up suffering because of the gradual expansion of the offer of public schools in the first decades of the 20th century and the everincreasing integration between the population of German origin and the "external world" in relation to the communities that had been altering their European-based ethnical traces by virtue of the necessary learning of Portuguese and the extra-familiar daily coexistence and of work relations in the agriculture, commerce, and emerging industry.

It is a fact that after that period of repression some schools have continued its activities, some as private teaching institutions, and others as members of the public municipal and state systems.

To exemplify, we can remember that there is currently the one of the Rede Sinodal de Educação (Synodal Education Network), linked to the Evangelical Church of Lutheran Confession in Brazil (IECLB), which preserves Luther's ideas in defense of a public school that forms good citizens. It characterizes, thus, a model of confessional education in the Brazilian context that seeks to keep its differentials and commitments built in the course of history. According to the official IECLB website, among the founding values of life oriented by the ideal of Luther are identity, community, and ecumenicity. This identity, as one has sought to show, has been built in Brazil in a scenario of struggles:

As for the education system implanted in Brazil in the second half of the 19th century by the Protestantism of mission - listed there Methodists, Presbyterians, Baptists, Congregationists, Adventists and Anglicans - it is rather different from the one introduced by the Lutherans. The Germans have settled mainly in rural areas, while the Protestantism of mission has searched for the towns. (http://www.luteranos.com.br/portal/site/conteudo.php?idConteudo=11769). 
Therefore, in the process of internationalization of ideas, Lutheranism arrives in Brazil and later consolidates itself in a Protestant school proposal as a natural complement to church, on a basis of doctrinal orientation that has led the immigrants to build a work that should turn the children away from illiteracy, giving the conditions for them to learn the bases of Lutheranism expressed in the Bible and in other documents. That is:

\begin{abstract}
In Luther's vision, who was a professor at the University of Wittenberg from 1508 to 1546, the year on which he died, the teacher was also a catechist, once the school had as a task to form good citizens. With the discovery of the salvation free of charge, of the justification by grace and faith, the focus of teaching, for Luther, has also changed. [As a result of this], the Synodal Network has been convoking the teachers' Congress every two years, since 1953, reuniting educators and representatives of the 58 schools integrated to the network, in a total number of 32 thousand students, in six Brazilian states - Rio Grande do Sul, Santa Catarina, Paraná, São Paulo, Rio de Janeiro, and Mato Grosso. (http://www.luteranos.com.br/portal/site/conteudo.php?idConteudo=11769).
\end{abstract}

As a fruit of the course of the historic situation presented, we have today the seat of the IECLB in the State of Rio Grande do Sul. Also there the Universidade do Vale do Rio dos Sinos (UNISINOS) is situated, an important center of preservation and irradiation of Lutheranism for the Brazilian society. Another active upper-level institution in Brazil is the Universidade Luterana do Brasil (ULBRA), maintained by the São Paulo Lutheran Evangelical Community (CELSP), the first school of which was founded in 1911(http://www.ulbra.br/sobreaulbra/). And many are the schools and high schools devoted to the Basic Education scattered across Brazil and linked to the Lutheran confession.

Another aspect that makes evident the permanence and vigor of the Lutheran conceptions in Brazil are the festivities for the Jubilee of the 500 years of the Reform. The celebrations are happening in the year of 2017, once in 1517 Martin Luther affixed the 95 theses on the door of the Wittenberg Castle Church and left to posterity a heritage that has transformed Christianity on the basis of a proposal of religious training intimately linked to school. In Brazil, the faith and education model proposed by Luther, which has arrived through the German immigration, continues giving fruits

\title{
Bibliographic references
}

BECK, N. L. J.. Educação. In: LUTERO, M. Obras Selecionadas. São Leopoldo: Sinodal, Porto Alegre: Concórdia. v.5., 1995 p.299-301.

BOUMENY, H. M. B.. Três decretos e um ministério: a propósito da educação no Estado Novo. In: PANDOLFI, D. Repensando o Estado Novo. Rio de Janeiro: Ed. Fundação Getúlio Vargas, 1999, p. 137-166. 
DREHER, M. N.. Entre a Idade Média e a Idade Moderna. In: Entre a Idade Média e a Idade Moderna. (Org.) Reflexões em torno de Lutero. v. II. São Leopoldo: Sinodal, 1984, p. 29-42.

DREHER, M. N.. Lutero e a Dieta de Worms de 1521. In: DREHER, M. N. (Org.) Reflexões em torno de Lutero. v. II. São Leopoldo: Sinodal, 1984, p. 79-91.

FERNÁNDEZ-ARMESTO, F. WILSON, D.. Reforma: O cristianismo e o Mundo 1500 - 2000. Rio de Janeiro: Record, 1997.

FISCHER, J.. Quem é Lutero no Brasil? In: DREHER, M. N. (Org.) Reflexões em torno de Lutero. v. II. São Leopoldo: Sinodal, 1984, p. 53-77.

GOBBO, F.. Cultural Continuity, Education, and Religious Identity: the Case of the Italian Waldensians. In: KUCERA, M; ROCHEX, J.; STECH, S. The Transmission of Knowledge as a Problem of Culture and Identity. Prague: The Karolinum Press, 2001, p.27-49.

http://www.luteranos.com.br/portal/site/conteudo.php?idConteudo=1158. Acesso em: 18 mar. 2012.

http://www.luteranos.com.br/portal/site/conteudo.php?idConteudo=11769. Acesso em: 18 mar. 2012.

http://www.ulbra.br/sobreaulbra/. Acesso em: 18 mar. 2012.

KLUG, J.. Imigração e luteranismo em Santa Catarina: a comunidade alemã de Desterro Florianópolis. Florianópolis: Papa Livro, 1994.

KREUTZ, L.. A Escola Teuto-Brasileira Católica e a Nacionalização do Ensino. In: MÜLLER, T. L. (Org.). Nacionalização e imigração alemã. São Leopoldo: Ed. Unisinos, 1994, p.27-64.

LAGENEST, J. P. B.. Elementos de Sociologia da Religião. Petrópolis: Vozes, 1976.

LUTERO, M.. Uma Prédica para que se Mandem os Filhos à Escola 1530. In: Obras Selecionadas. São Leopoldo: Sinodal, Porto Alegre: Concórdia, v.5, 1995, p.326-363.

LUTERO, M.. Aos Conselhos de Todas as Cidades da Alemanha para que criem e mantenham escolas cristãs. In: Obras Selecionadas. São Leopoldo: Sinodal, Porto Alegre: Concórdia, v.5, 1995, p.302-325.

MÜLLER, T. L. (Org.). Nacionalização e imigração alemã. São Leopoldo: Ed. Unisinos 1994.

MÜLlER, T. L. (Org.). A Nacionalização e a Escola Teuto-Brasileira Evangélica. In: A Nacionalização e a Escola Teuto-Brasileira Evangélica (Org.). Nacionalização e imigração alemã. São Leopoldo: Ed. Unisinos, 1994,65-74.

NAGLE, J.. A educação na primeira república. In: HOLLANDA, S.B. História geral da civilização brasileira. 4.ed., Tomo III, v. 2, livro 3º, 1997, p. 261-291.

RAMBO, A. B.. A Escola Comunitária Teuto-Brasileira Católica, a Associação de Professores e a Escola Normal. São Leopoldo: Ed. UNISINOS, 1996.

SANTOS, A.V.. Educação e nacionalismo: configurando a escola primária catarinense na Era Vargas. Revista Brasileira de História da Educação. n.24,p. 84-111, set./dez. 2010.

SANTOS, A.V.. A política educacional nacionalista e o aspecto linguístico: vestígios na escola primária. Revista Brasileira de Estudos Pedagógicos. Brasília, v.90, n.225, p.511-527, maio/ago. 2009. 
SANTOS, A.V.. Práticas educativas em escolas alemãs de acordo com relatórios da Companhia Colonizadora Hanseática de Hamburgo. In: ANPED, 31, Anais, Caxambu, 2008, CD-ROM.

SCHNEIDER, A. B.. Povoamento-Imigração-Colonização: A Fundação de Blumenau (no Vale do rio Itajaí) e de Joinville (nos fundos do Termo (Município) de Nossa Sra. Da(s) Graça(s) de São Francisco Xavier (ou de Assis) do Sul. Joinville, 1983.

VOLKMANN, M.. Lutero e a Educação. In: DREHER, M. N. (Org.) Reflexões em torno de Lutero. v. II. São Leopoldo: Sinodal, 1984, p. 93-105.

WEINGAERTNER, N.. XV Concílio Regional da 2 $^{\text {a }}$ Região Eclesiástica da IECLB, 1997. (impresso).

WEREBE, M.J.G.. A educação. In: HOLANDA, S.B. História geral da civilização brasileira. 5.ed,. t. 2, v.4, 1995, p. 366-383.

WILLEMS, E. A.. A aculturação dos alemães no Brasil. 2.ed. São Paulo/Brasília: Ed. Nacional, INL, 1980.

\section{Documental sources}

AUSZUG aus den Schulberichten im Bezirk Itapocú pro 1904. Hammonia, 1905.

COMUNIDADE EVANGÉLICA DE CORUPÁ. [194?]. Carteira de Identidade Eclesiástica no. 00099.

FRÜCHTING, W. J. O. Interview. Corupá, jun.; jul., 1998.

Hinos da Igreja Evangélica de Confissão Luterana no Brasil, [s.d.]

JAHRESBERICHT 1904 über die 5 Hansaschulen des Bezirks Hercilio, erstattet von Schulinspektor Dr. Aldinger. Hammonia, 1905.

OBRIGAÇÃO. Hansa, 1929.

TÍTULO DEFINITIVO DE PROPRIEDADE, Hammonia, 1918.

\section{Revisores}

\begin{tabular}{l|l} 
Língua Portuguesa & $\begin{array}{l}\text { Nome: Marí Neiva Rodrigues dos Santos } \\
\text { E-mail: promarineiva@gmail.com }\end{array}$ \\
Língua Inglesa & $\begin{array}{l}\text { Nome: Marí Neiva Rodrigues dos Santos } \\
\text { E-mail: promarineiva@gmail.com }\end{array}$ \\
Língua Espanhola & $\begin{array}{l}\text { Nome: Marí Neiva Rodrigues dos Santos } \\
\text { E-mail: promarineiva@gmail.com }\end{array}$
\end{tabular}

